\title{
Kültür Varlıklarının Korunmasının ve Algılanabilirliklerinin Sağlanmasının Yönetsel ve Hukuksal Boyutu: Malatya Karakaş Konağı
}

Doç. Dr. Yüksel Göğebakan

Makale Geliş Tarihi: 20.12.2017 Yayına Kabul Tarihi: 04.05.2018

\section{Özet}

Neolitikten Tunç Çağına, Asurlulardan Hititlere, Urartulardan Bizanslilara kadar birç̧ok farklı toplulukların/ devletlerin yaşandı̆̆ı ve kültürel izlerinin taşındığı Malatya ve çevresinde Anadolu Selçuklularla başlayan Türk hâkimiyeti Osmanlılarla devam etmiş ve Cumhuriyetle birlikte de günümüze kadar gelmiştir. Kentte tarihsel geçmişin izlerini taşııan kültür varlığı konumunda olan eserlerin büyük bir çoğunluğu Geç Osmanlı ve Erken Cumhuriyet dönemine aittir. Osmanlı dönemine ait olan eserlerden birisi de 1875-1880 tarihleri arasında inşa edilen, dönemin kültürel izlerini tașıyan ve mimari yapılanması hakkında önemli bilgiler veren sivil mimarlık örneği olarak tescillenen Karakas Konağı'dır. Tescilli kültür varlı̆̆ı konumunda bulunan bu yapının korunması ve algılanmasııın sağlanması ile ilgili olarak yapilan yönetsel ve hukuksal çalışmaların ortaya konulması, bu

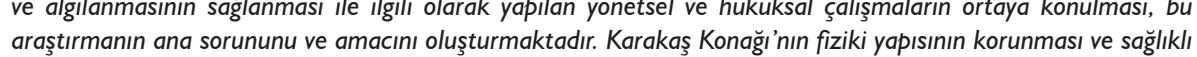
bir șekilde algılanabilmesi için yapılan yönetsel ve hukuki yaklaşımlar, hem bölge hem de ülke olarak bu tür yapılara bakış bakımından aydınlatııı bilgiler vermekte olup, örnek niteliği taşımaktadır.

Anahtar Kelimeler: Koruma, Kültür Varlı̆̆, Malatya Karakaş Konağı

CONSERVATION OF CULTURAL PROPERTIES AND THE ADMINISTRATIVE AND LEGAL DIMENSIONS OF ENSURING THEIR PERCEPTIBILITY: THE CASE OF MALATYA KARAKAS MANSION

\section{Abstract}

One of the nations that have established domination in Malatya and its surrounding where many different communities/states from the Neolithic to the Bronze Age, from the Assyrians to the Hittites, from the Urartians to the Byzantines lived the Turkish period that started with the Anatolian Seljuks in the region continued with to the Byzantines lived the Turkish period that started with the Anatolian Seljuks in the region continued with city harly Turkish Republical which was cons which was cons Re as an example of civil archicecture, giving important information about its architectural structure. To reveal the administrative and legal studies on the consenvtion of this structure wh the feature of a registered cultural

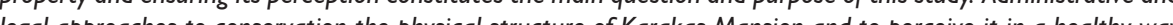
legal approaches to conservation the physical structure of Karakass Mansion and to perceive it in a healthy way provide enlightening information with respect to our point of view on these kinds of buildings both in the region and in the country and have an exemplary feature.

Keywords: Conservation, Cultural Property, Malatya Karakaş Mansion 


\section{Giriş}

Pluwat doğal kaynaklar açııından fakir bir ada, bu yüzden ada sakinleri intiyaçlarını ancak öbür adalara yaptıkları seferler ile karşılayabiliyorlar. Adalılar Fransız hegemonyası altına girdikten sonra, Fransız hükümeti yerlilerin bütün ihtiyaçlarını kendi gemileri ile karşılamaya başlar; fakat Pluwatılıar yine eskiden olduğu gibi, ağaçtan oydukları kanolara binip bildiklerini okurlar. Yolcular arasında yalnız yetişkin erkekler değil, kadınlar, çocuklar ve yaşıılar da vardır. Bu yolculuklar ufak gezintiler değil, günlerce, bazen haftalarca süren, yüzlerce kilometreyi kapsayan seferlerdir. Böyle bir sefere katılan ünlü antropolog Thomas Gladwin, East is a Big Bird (Doğu Büyük Bir Kuştur) adlı kitabında, eğer bu seferler yapılmazsa Pluwatılıarın ne geçmişi ne de geleceği olur, der (Sargun A. Tont, Sulak Bir Gezegenden Öyküler).

Kültür varlıkları, toplumların geçmişleri ve dolayısıyla da yaşanmışlıkları hakkında bilgi veren birer tarihi vesika olarak, gelecek kuşakların geçmişe ait değerler hakkında bilgi sahibi olmalarının yanında, onların, geleceği şekillendirmelerine de vesile olacak öneme sahiplerdir. Bu eşsiz ve yeri doldurulamaz eserlerin korunması ve devamlııklarının sağlanması bir toplumun varlık nedeni olduğu içindir ki, korunmaları ve devamlılıklarının sağlanması bir zorunluluk arz etmektedir. Hal böyle iken özellikle ülkemizde tarihsel ve kültürel değere sahip birçok kültür varlığı konumundaki eserlerin sağlıklı bir şekilde korunmadığı ya da korunamadığı üzücü bir gerçek olarak ortada durmaktadır. Korumada yaşanan bu durumun bir neticesi olarak, hem sosyal hem de hukuki bakımdan ciddi manada olumsuzlukların yaşandığını görülmektedir. Ülkemizin birçok bölgesinde olduğu gibi zengin tarihsel ve kültürel geçmişe sahip bir şehir olarak Malatya'nın ve çevresinin de, benzer olumsuzluklara maruz kaldığını germek mümkündür. Malatya civarındaki en eski höyüklerden birisi olan Caferhöyük'teki yerleşimin M.Ö. 7000'li yıllara kadar uzandığı düşünüldüğünde, bölgedeki tarihsel geçmişin ne kadar derin bir yapıya sahip olduğunu kendiliğinden ortaya çıkmaktadır. Bu veriler de bölgenin tarihsel ve kültürel anlamda çok zengin bir yapıya sahip olduğunu göstermektedir.

Malatya şehir merkezinde bulunan ve Osmanlı'nın son dönemine ait bir yapı olan Karakaş Konağı da, bu zengin miras hakkında ipuçları veren bir yapı olma özelliğine sahiptir. Tescilli kültür varlığı olarak envantere kayıtlı olan bu yapının yönetsel ve hukuki bakımdan yaşamış oldukları, ülkemizde kültür varlıklarının hak ettikleri değeri çok da göremediğini ortaya koymaktadır (Görsel 1). Yapının çevresinde sağlıklı kamulaştırmanın yapılmaması ve etrafına yapıyı ezecek nitelikte iş merkezlerinin/binaların inşa edilmesi, var olan olumsuz durum hakkında fikir vermektedir. Yapılan bu çalışmada, yapının etrafına inşa edilen iş merkezlerinin, kültür varlığı niteliği taşıyan
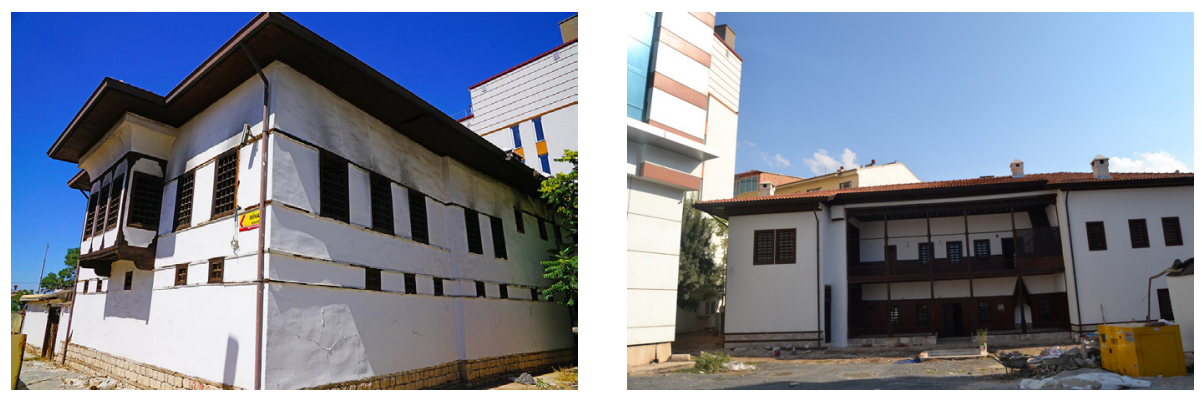

Görsel I. Karakaş Konağı Güney Batı Cephesi (Solda)

Görsel 2. Karakaş Konağı Cephe Giriş/Kuzey Cephe Görünümü (Sağda)

bu tarihi yapının nasıl kaybolmasına, görünebilirliği ve algılanabilirliğinin ortada kalkmasına neden olduklarını göstermektedir. Yapının bulunduğu 1324 ada içerisinde yer alan 2, 3, 4, 5, ve 6 No.lu parsellerde yapılaşmaya gidilmiş ve bu yapılaşma neticesinde tescilli konağın etrafı adeta duvarlarla çevrilmiş gibi bir görünüme bürünmüştür. Aynı ada içerisinde bulunan ve yapının batı cephesini boydan boya kapatan 1 No.lu parselde daha önce yapılaşmaya gidilmemiş ve buradaki yapılaşma ile ilgili olarak bir çalışma yapılmış ve bu çalışma neticesinde ise, Adana ve Sivas Kültür Varlıklarını Koruma Bölge Kurulları mevcut parsele imar izni vermiş, bu imar izni de Malatya Belediyesi tarafından kabul görmüştür. Ancak Malatya II Özel İdaresi, 1324 ada 1 No.lu parsel için verilen imar izninin iptali için Kültür ve Tabiat Varlıklarını Koruma Yüksek Kurulu'na itirazda bulunmuş ve Yüksek Kurul da bu itirazı haklı görerek adı geçen parseldeki imar iznini durdurmuş ve bunun neticesinde de olay yargıya intikal etmiştir. Yapılan hukuki mücadele çerçevesinde konuyla ilgili olarak bilirkişiye başvurulmuş olup, yazar da bu dava için belirlenen üç bilirkişiden birisi olmuştur. Bu çalışma; Karakaş Konağı'nın batı cephesinde bulunan 1324 ada 1 No.lu parselle ilgili olarak hazırlanmış olan bilirkişi raporundan yola çıkılarak hazırlanmıştır. Yapı ile ilgili olarak yönetsel ve hukuki alanda yaşananlar, ülkemiz açısından da bir örnek niteliği taşımaktadır.

\section{Malatya Karakaş Konağı ve Yönetsel Bakımdan Koruma Sorunu}

Malatya Niyazi Mısri Caddesi'nde bulunan ve Karakaşı $\mathrm{Hacı}$ Mustafa Efendi tarafından 1875-1880 tarihleri arasında iki katı kerpiç malzemeden inşa edilmiş olan Karakaş Konă̆ı'nın esas girişi bahçeden verilen girişle sağlanmıştır (Görsel 2). Dikdörtgen planlı olan yapının boyutları $12,60 \times 23,70$ m'dir. Osmanlı dönemine ait bir sivil mimarlık örneği niteliği taşıyan yapı, bahçe tarafından yerden yaklaşık olarak $40 \mathrm{~cm}$ yükseklikte bir eyvana sahiptir. Bu durum aslında yapıya bir ferahlık sağlamaktadır. 
Bu eyvanda aynı zamanda, girişin sağ tarafında, bir davlumbazlı ocak yeri de bulunmaktadır. Aynı eyvandan ahşap bir kapı ile 2 salon ve 6 odanın bulunduğu zemin kata geçilmektedir (Görsel 3).
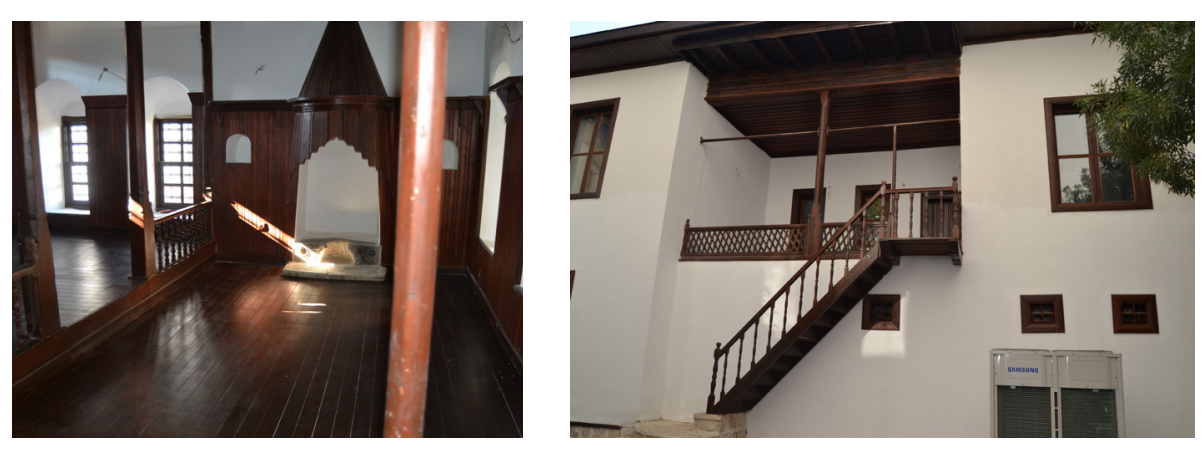

Görsel 3. Karakaş Konağı Zemin Kat (Solda)

Görsel 4. Karakaş Konağı Güney Cephe Görünümü (Sağda)

Yapının birinci katına iki ayrı çıkış bulunmaktadır. Bunlardan birisi bahçe tarafından yapının doğusunda bulunmakta ve dışarıdan ahşap bir merdivenle sağlanmaktadır. Diğer çıkış ise ana giriş kapısının sağında yer alan ve yapının içinde bulunan ahşap merdivenli bölümdür. Bahçe tarafından yukarı kata çıkışı sağlayan merdivenin bulunduğu kısımda geniş bir eyvan mevcut olup balkon görünümündedir (Görsel 4). Buradan da yine ahşap bir kapı ile 2 salon ve 6 odadan oluşan birinci kata girilir (Görsel 5). Buradaki odalardan birisi ahşap çıkma ile caddeyi görür nitelikte olup genişletilmiştir. Yapıdaki genel görünüm tümüyle bahçe yönüne hakim bir durum arz etmektedir. Batı cephesi yüzeyinde bulunan çıkma kale görünümlü yapının cephe yüzeyinde bir hareketlilik sağlamaktadır (Görsel 1). Birinci kata çıkışı sağlayan diğer ahşap merdiven ise binanın içerisinde girişin sağ tarafında yer almaktadır (Görsel 6). Yapı orijinal görünümünü zamanla yapılan onarımlarla ciddi anlamda yitirmiştir (Görsel 7). 2000-2001 (Görsel 8) ve 2008 yıllarında (Görsel 1) restore edilen ve bir restorasyon çalışması da günümüzde (2017) devam eden konak, devrinin bağ evleri özelliğini tamamen üzerinde taşımakta ve geleneksel Malatya evleriyle ilgili olarak her yönüyle bilgi verir niteliktedir (Malatya Kültür Envanteri, 2014: 99). Konak, klasik anlamda bir Türk evi niteliği taşımasından dolayıdır ki, geleneksel Malatya konut mimarisi hakkında vermiş olduğu bilgi bakımından da önem taşımaktadır.

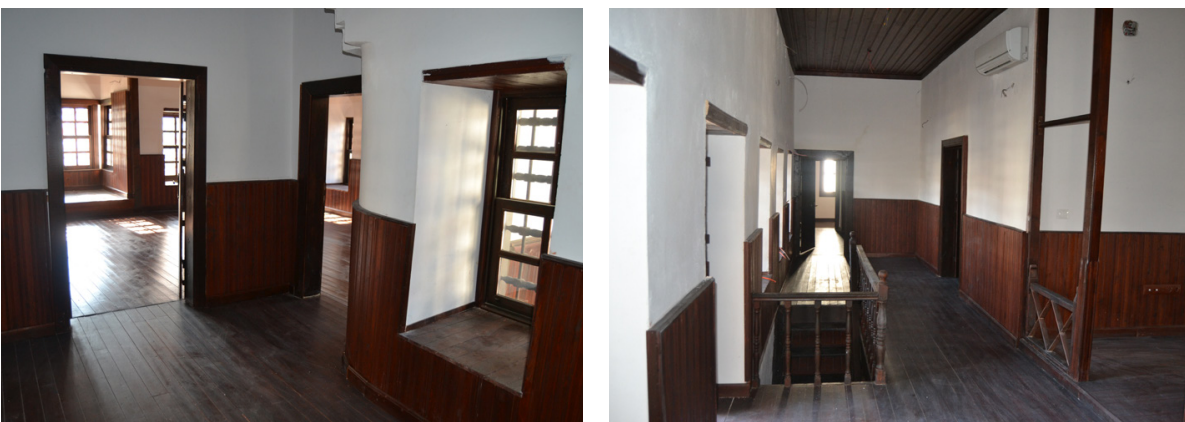

Görsel 5. Karakaş Konağı I. Kat (Solda)

Görsel 6. I. Kata Çıkışın Sağlandığı Merdivenli Görünümü (Sağda)

Tarihsel nitelik taşıyan bu konak, farkı ıönemlerde yapılan restorasyonlarla ayaktatutulmayaçalışılmış; ancakçokyüksekbütçeliharcamalaryapılmasına rağmen tam anlamıyla kimliğini koruyamamış, ilk halinden/orijinalinden çok farklı bir görünüm kazanmışıtı. Nitekim yapılan restorasyonlarda yapının genel görünümünde yaşanan büyük değişimler süreç hakkında bilgi verir niteliktedir.

Yapının ilk dönemlerine ait görseller, kültür varlığı konumundaki bu yapının onarımlarla nasıl bir değişime uğradığını göstermektedir. Nitekim 2000-2001 yıllarında yapılan onarımın yapının önceki görüntüsüyle hiçbir örtüşen yönünün olmaması gibi, 2008 yılında yapılan onarımın da daha önce yapılanla hiçbir benzerliği bulunmaktadır. Bu durum da yapının onarımında ne vahim hatalar yapıldığını ortaya koymaktadır.

Kültürel değere sahip bir yapının restore edilip edilmemesi de zaten koruma bilincinin şekillendiği 18. yy'dan itibaren devamlı tartışma konusu olmuştur. Nitekim İngiliz ressam ve sanat eleştirmeni John Ruskin (1819-1900) The Seven Lamps of Architecture (1849) adlı yapıtında, üslup birliğine ulaşmak için eklerin kaldırılması ve yerlerine, tam bilinmeyen, ama sözde ilk üsluba uygun tasarımların yapılması girişimlerini reddetmiş; hiçbir müdahalede bulunmamanın daha doğru olduğuna inanmış ve yapılan her müdahaleyi de yama olarak değerlendirmiştir (Ahunbay, 2014: 14). Yapıların onarılarak değiştirilmesine karşı çıkarak, sanat eserinin bugüne gelen biçimiyle korunması gerektiği ve eserle ilgili hiçbir şey yapılmamasının daha doğru olduğunu belirtmiş olup bu görüş yakın zamanda oldukça fazla taraf bulmuş ve modern zamanların en çok tercih edilen koruma anlayışı halini almıştır. Ruskin bu yaklaşımla ilgili olarak şunları söylemektedir: 
Anıtlarınıza iyi bakınız; o zaman restorasyona gerek kalmayacaktır... Restorasyon bir yapının başına gelen en büyük felakettir. Öyle bir felakettir ki hiçbir şey kurtulamaz ve yok olanın kötü bir benzeri getirilir. Bu önemli konuda kimseyi aldatmayalım nası ölüleri diriltmek olanaklı değilse, mimarlıkta da bir zaman muhteşem ve güzel olanı restore etmek olası değildir (Erder 1975'den aktaran Ahunbay, 2014: 14)
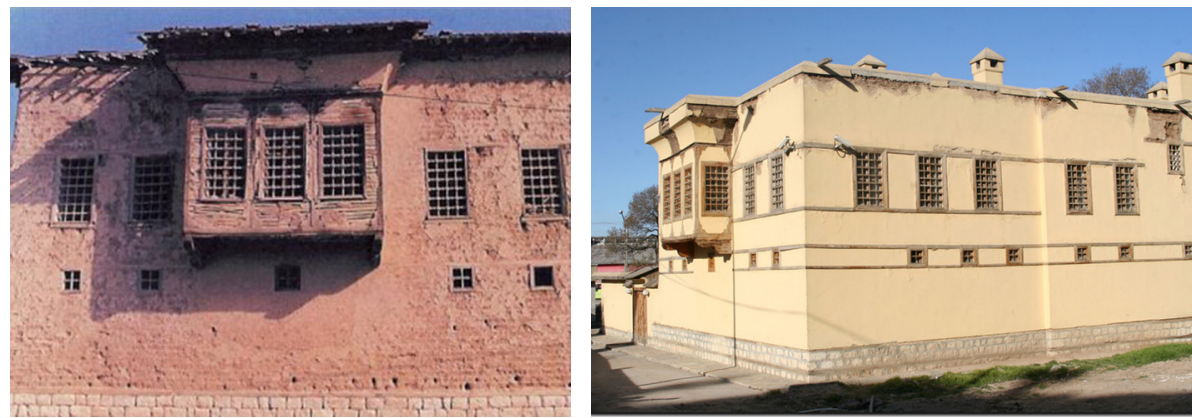

Görsel 7. Konağın Restorasyondan Önceki Görünümü (Solda)

Görsel 8. Konağın 2000-200I Yıllarındaki Restorasyondan Sonraki Görünümü (Sağda)

Ruskin'e göre anıt zamanının yetebildiği sürece ayakta tutulmalı, sahte bir kopya onun yerine verilmemelidir. Burada aslında sanat eserine dokunulmaması/müdahalede bulunulmaması gerektiği görüşü ortaya konulurken, eser için hiçbir şey yapılmaması gerektiğini ifade etmiştir. Bu da yaklaşımın "Anti restorasyon" akımı olarak adlandırılmasına neden olmuştur. William Morris bu akımın çok daha geniş kitlelere ulaşmasına neden olmuştur. Morris yapılan restorasyonları şöyle eleştirmektedir:

Son elli yıldır (1827'den beri) adeta başka bir duyu gibi, tarihi sanat eserlerine yeni bir ilgi uyanmış; bu çalışma alanı dini, tarihi ve sanatsal merak konularından biri olmuştur. Bu zamanımızın tartışılmaz kazançlarından biridir. Ancak düşünüyoruz ki, eğer şu anda yapılmakta olan işlemler böyle sürerse, gelecek kuşaklar bu eserleri araşıırmaya değer bulamayacaklar, ilgisiz kalacaklardır. Kanımızca son elli yılın restorasyonları daha önceki yüzyılların ihtilal, şiddet ve aşağılamalarının neden olduğu tahripten daha fazlasını yapmıştır (Harvey 1972'den aktaran Ahunbay, 2014: 15).

Karakaş Konağı dayaşamışolduğu restorasyon çalışmalarıyla orijinalliğini kaybetmiş, karakteristik özelliğini yitirmiştir. Yapının uzun bir dönemi barındıran üzerindeki yaşanmışlıklar tamamen ortadan kaldırılmış, onun yerine adeta maket görünümlü, kusursuz olarak yapılmış bir görüntü ortaya konulmuştur. Karakaş Konağı'nın ayakta kalmasına katkı sağlaması bakımından belli bir amaç doğrultusunda kullanılmasının yararlı olacağı düşünülmüş; ancak yapı hiçbir zaman böyle bir kullanıma sahip olmamıştır. İşe bu durum da devamlı konağın tahrip olmasına ve karakterindeki nadide yapının yok olmasına neden olmuştur. Aslında konak herhangi bir işlevsellik kapsamında kullanıma açılsa idi belki de durum çok daha farklı olacaktı. Nitekim geçmişi, var olanı dondurmak saklamak, çağın insanı için yaşanmaz duruma getirmek koruma değildir

Çağı yakalayamayanların, günlerinden korkup kaçanların, sonunda düştükleri geçmiş özlemi, yaşamı durdurmaya kalkışmaya dek vardırmalarına neden olmaktadır (Bektaş, 2001: 23).... Boş kalan ev, insansız kalan ev yaşayamaz. Yaşamı koruyamayan hiçbir girişim, insanlık adına olumlu bir girişim olamaz. Bi kaplumbağa kabuğu, içinde canlı yoksa üzünç veri. Kuşaklar boyu kapalı tutulan bir yapı, onların kültürlerine girer mi? Kültürü yaşayabilmenin, onu yaşatabilmenin, çağdaşını yaratabilmenin yolları açık tutulmalıdır. Asıl korunacak olan bu yaratmadır. Bu da geçmişle bugünün, bugünle geleceğin ilişkilerinin sağlıklı, canlı, alış-veriş içinde; katkılara, yeni üretimlere açık tutulmasıyla olanaklıdır (Bektaş, 2001: 24).

Ancak bir yapının belli bir amaç doğrultusunda kullanılması ile yapının bu amaç doğrultusunda orijinalliğini kaybettirilmesi (eklemelerde, çıarımlarda bulunulması), etrafına yapının görünülebilirliğini olumsuz yönde etkileyen yapıların inşa edilmesi farklı şeylerdir. Genelde yapılan en büyük hata, böyle bir kültür varlığının kullanıldığı amaç doğrultusunda deforme edilmesi, nadide yapısının ortadan kaldırılması ya da yapının etrafına çeşitli ilavelerde bulunulmasıdır.

\section{Konağın Restorasyonunda Yaşanan Bürokratik Süreç}

Karakaş Konağı ile ilgili olarak Kültür ve Turizm Bakanlığı tarafından 2001 yılında restorasyon çalışmaları için 3 ayrı ihale sonucunda yaklaşık olarak 530 bin TL bir harcama yapılmış ve yapının Etnografya Müzesi ve Malatya Evi olarak kullanılmasına karar verilmiştir. 2003 yılında restorasyon neticesinde teslimi yapılan konağın (bu restorasyonda konağın çatısı yapılmamıştır), 2004 yılında Etnografya Müzesi olarak kullanılmasına yönelik çalışmalar devam ederken, çatısı olmamasından dolayı, daha doğrusu orijinalinde olan çatısının yapılamamasından dolayı, kerpiç binaya sular sızmış ve yapının kerpiç duvarları dökülmeye başlamıştır. Yapı tekrar çatısı ve iç dizaynı doğrultusunda onarılmıştır. Yani yapı aslında restorasyondan sonra daha hizmete girmeden dökülmeye başlamıştır.

Ana sorunlardan birisi de yapının görünümünü yani algılanabilirliğini sağlayan çevresiyle ilgili yaşananlardır. Yapının etrafındaki 2 bin 544 metrekare alanın kamulaştırmasının yapılması gerekmiştir. 2005 yılında 
dönemin Il Kültür Müdürü yapı için 200 bin TL ödeneğe ihtiyaç olduğunu ve aynı zamanda konağın güvenlik görevlisi ihtiyacı olduğunu da belirtmiştir. Fakat kamulaştırma ile ilgili herhangi bir işlem yapılamadığı için, ortaya çıkan bu boşluğun da bir neticesi olarak, yapının çevresindeki boş alanlara iş merkezleri yapılmışıı. 2006 yılında İstanbul merkezli Malatya Eğitim Vakfı, konağı "Geçmişten Geleceğe Malatya Kültür Evi" olarak işletmek için talep etmiştir. Bu taleple ilgili olarak Kültür ve Turizm bakanlığı nezdinde girişimler devam ederken, konağın Milli Emlak Müdürlüğü tarafından Malatya II Özel İdare Müdürlüğ̈̈'ne devri gündeme gelmiştir. Bir süre sonra konak, II Özel İdaresi'ne devredilmis ve yağmur suyunun konağın içine dolmasından dolayı Sivas Kültür ve Tabiat Varlıkları Koruma Kurulu'nun kararıyla Mayıs 2007'de çatısı yapılmıştır. 2007 yılında Malatya Valiliği, konağın Malatya geleneksel mahalli yemeklerinin sergileneceği, kültür ve sanat merkezi olarak turizm amaçlı kullanılacağını belirtmiştir. Bu yönde çalıșmalar henüz sonuçlanmadan 2007 yllında îl Özel İdare'ye devri yapılan konak, bu defa da 2009 yılında Vakıf Müzesi olma talebiyle Kültür ve Turizm Bakanlığı'na devredilmiştir. Vakıf Müzesi olma talebini dikkate alan Bakanlık, konağı süresiz olarak Vakıflar Bölge Müdürlüğü'ne devretmiştir. Yapılacak 76 bin TL ödenekle müzeye dönüşmesi düşünülen yapının bu defa da Valilik tarafından Türkiye Seyahat Acentaları Birliği'ne (TÜRSAB) verileceği ve bununla da kurumun, Malatya'nın tarihi ve kültürel yerlerini tur kapsamına alacağı belirtilmiştir. Bu da tam netleşmeden bu defa konağın, 12 Ağustos 2011 tarihinde, Türkiye Barolar Birliğince restore edilerek Malatya Barosu binası olarak kullanılmasına karar verildiğini açıklamışır. 23 Kasım 2011 tarihinde imzalanan protokolle konak 33 yıllı̆̆ına Barolar Birliğine devredilmiştir. Baronun konağın onarımı için 192 bin TL gönderdiği ve binanın lokal ve hukuk merkezi olarak kullanılacağı belirtilmiştir. Ancak konak hizmete açılmadan Eylül 2013 yılında yeniden Barolar Birliğinden alınarak II Özel İdaresi'ne 33 yıllığına kiralanması kabul edilmiş ve Barolar Birliğinin ödemiş olduğu 192 bin TL'nin Barolar Birliğine ödenmesi kararlaştııılmıştır.

Tüm bu yaşananlardan sonra ve milyonlarca lira para harcandıktan sonra konak, Kasım 2014'de Malatya Büyükşehir Belediyesi'ne devredilmiştir. Güvenliği sağlanamayan konakta uyuşturucu kullanımına kadar varan illegal amaçı kullanımlar başladı. isste bu durumun bir neticesi olarak da Nisan 2015'de bilinmeyen bir nedenle konakta yangın çıktı ve bu yangın sonucunda yapı büyük hasar görmüştür. Yaklaşık olarak 14 yıllık bir restorasyon dönemi yaşayan konakta meydana gelen hasar, tüm

http://tayproject.org/haberarsiv20142.htm harcamaları boşa çıkarmış ve anlamsızlaştırmıştır. Yapıdaki güvenlik kameralarının çalışmamasından dolayı yangının neden kaynaklandığı tespit edilememiş; ancak mekânda kontrolün sağlanamamasından dolayı uyuşturucu bağımlıları tarafından bu yangının çıkarıldığı tahmin edilmektedir. ${ }^{2}$ Konağın Malatya Büyükşehir Belediyesi'ne devrinden sonra da İmar ve Şehircilik Dairesi Başkanlığı Tarihi Mekânlar ve Kent Estetiği Şube Müdürlüğütarafından Rölöve-Restitüsyon-Restorasyon projeleri hazırlandı bu projeler, Sivas Kültür Varlıklarını Koruma Bölge Kurulu tarafından da onaylanmıştır. Yaklaşık bir yılda bitirilmesi düşünülen restorasyon Haziran 2016'da başlanmıştır. Yapılan restorasyonla yangında zarar gören ahşap elemanların tamamen yenileneceği, duvarlarında beton kullanılan alanların -bu yapının orijinalliğini tamamen ortadan kaldıran bir durum oluşturmaktadır- aslına uygun Horasan harcıyla yenileneceği belirtilmiştir. Diğer taraftan yapının yaşamış olduğu iklimsel ve fiziki tahribattan dolayı, gerekli görülen yerlerinde aslına uygun olarak statik güçlendirmesinin de yapılacağı belirtilmiştir. ${ }^{3}$

\section{Malatya Karakaş Konağı ve Hukuki Bakımdan Koruma Sorunu}

Malatya Ili Merkez Illçesi Niyazi Mahallesi'nde bulunan ve I. Grup Korunma derecesine sahip olan Karakaş Konağı, Adana Kültür ve Tabiat Varlıkları Koruma Kurulu'nun 01.06.1989 tarihli ve 356 sayllı kararı ile korunmas gerekli kültür varlığı olarak tescil edilmiştir. 210 pafta 1324 ada 7 parselde yer alan Konağın koruma alanı, Adana Kültür ve Tabiat Varlıkları Koruma Kurulu'nun 11.12.2001 tarih ve 4471 sayll kararı ile Kültür ve Tabiat VarIıklarını Koruma Yüksek Kurulu'nun 05.11.1999 tarih ve 664 sayılı İlke Kararı uyarınca belirlenmiştir. Adana Koruma Kurulu 14.07.2003 tarih ve 5212 sayılı kararında konağın etrafındaki yapılaşmayla ilgili şöyle bir tanımlama yapmışır: Karakaş Konağı koruma alanında özel mülkiyete ait 210 pafta, 1324 adada yer alan 1-2-3-4-5 No.lu parsellerde $h=12,50$ metre, 6 No.lu parselde $h=6,50$ metre ve 1-2 No.lu parsellerde en az arka bahçe mesafesi 5 metre, 3-4-5 ve 6 No.lu parsellerde en az 3 metre olmak üzere kültür varlı̆̆ı parsel sınııına yapı yaklaşma mesafesi olarak bırakılmasına karar vermiştir (Görsel 9-10). Burada kültür varlığı ile yapı arasındaki yapı yaklaşma mesafenin en az 3 metre olarak değerlendirilmesi mevcut kültür varlığının algılanabilirliğini olumsuz yönde etkileyen bir faktör olmuştur. Özellikle etrafta yer alan yapıların gabarisi, konakla mukayese edildiğinde, bu yapı yaklaşma mesafesinin kısalığını iyice gün yüzüne çıkmaktadır. 1999 yılında 1324 ada 1 No.lu parselin sit alanı dışında kaldığı gerekçesiyle imar planında yapı nizamı bloku 5 kat olarak belirlenmişken, Adana Koruma Ku-

hatp /lwww malyasonsoz com tr/haber-34590-Karakas Konagi yandi htm

http://www.malatya.bel.trl/icerik/18/2969/karakas-konagi-aslina-uygun-restore-ediliyor.aspx 
rulu'nun bu kararına istinaden önceki planlardaki 5 katlı inşaat yoğunluğu 4 kata indirilmiştir. Konak etrafında 1 No.lu parsel hariç diğer parsellerde kurul kararı doğrultusunda yapılaşmaya gidilmiş ve kültür varlığı konumunda bulunan konağın gabarisinin çok üstünde bir görünüm ortaya çıkmıştır. Tescilli kültür varlığı olan konak, etrafındaki yapıların arasına sıkışıp kalmıştır (Görsel 11).
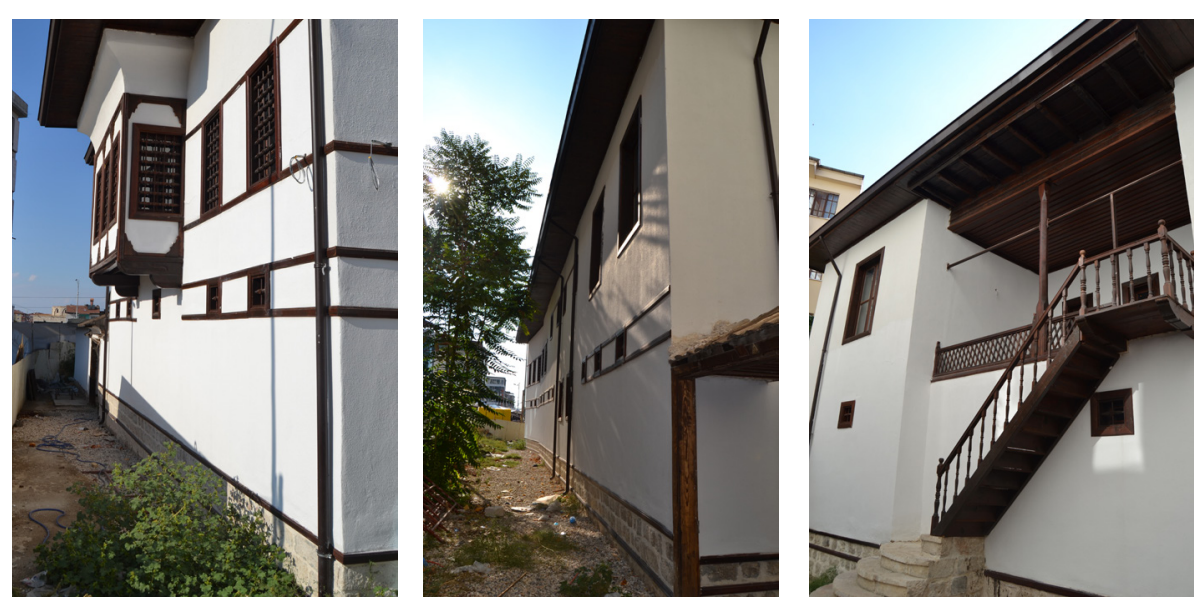

Görsel 9. Batı Cepheden Görünüm (Solda)

Görsel 10. Güney Doğu Cepheden Görünüm (Ortada)

Görsel II. Güney Cepheden Görünüm (Sağda)

Sivas Kültür ve Tabiat Varlıkları Koruma Bölge Kurulu kurulduktan sonra Malatya Bölgesi Adana Bölge Kurulu'ndan ayrılarak bu kurulun çalışma kapsamı alanına girmiştir. Sivas Bölge Kurulu'nun 31.01.2007 tarih ve 345 sayılı kararı ile Niyazi Mahallesi'nde sit alanı dışında, taşınmaz kültür varlığı olarak tescilli Karakaş Konağı'na cephe veren 1324 ada 1 ve 2 parsellerde önerilen blok nizam 5 kat, 0,40/2,00 yapı yoğunluğuna haiz yeni yapılanma projesine ilişkin imar plan tadilatının uygun olduğuna karar verilmiş ve karar ekindeki plan bu haliyle Sivas Kültür ve Tabiat Varlıkları Koruma Bölge Kurulunca onaylanmıştır. Kurulun 31.01.2007 tarih ve 345 sayılı kararı ve Malatya Belediye Meclisi'nin 02.05.2007 tarih ve 83 sayılı kararına istinaden 1 No.lu parselin 330.39 m2'lik kısmı bedelsiz olarak 20.04.2009 tarihinde yol terkini yapmıştır.

Sivas Kültür ve Tabiat Varlıkları Koruma Bölge Kurulu 13.10.2011 tarih ve 31 sayılı kararla; Kurulun 31.01.2007 tarih ve 345 sayılı kararıyla onayla- nan imar plan değişikliğinin daha sonra onaylanan Malatya Kent Bütünü Revizyon İmar Planı Çalışmaları kapsamındaki Merkez 3. Etap Revizyon Imar Planı'nda 31.01.2007 tarih ve 345 Kurul kararının aynen işlenerek uygun olduğuna karar vermiştir. Malatya II Özel İdaresi tarafından 26.01.2012 tarih ve 867 sayılı yazı ile 2863 sayılı Yasa'nın 61. Maddesi gereğince, 1 No.lu parselde yapılaşmaya gidilmesi durumunda konağın kütle ve gabarisi ile uyumsuz bir görüntü oluşturacağı gerekçesiyle Yüksek Kurul'a itirazda bulunulmuş ve Kültür Varlıklarını Koruma Yüksek Kurulu da 07.02.2012 gün ve 21 sayılı kararı ile; Sivas Kültür ve Tabiat Varlıkları Koruma Bölge Kurulu'nun 13.10.2011 tarih ve 31 sayılı kararına karşı bu itirazı kabul ederek, Niyazi Mahallesi 1324 ada 1 No.lu parselde herhangi bir yapılaşmaya gidilmemesine karar vermiştir. Sivas Kültür ve Tabiat Varlıkları Koruma Bölge Kurulu'nun 13.10.2011 tarih ve 31 sayılı kararının Yüksek Kurul tarafından iptal edilmesinin gerekçesi olarak da tescilli Karakaş Konağı'nın kütle ve gabarisi ile uyumsuz bir görünümün ortaya çıkacağı yapının özgün değerini kaybedeceği gösterilmiştir. Ancak burada şöyle bir durum söz konusudur ki, Sivas Bölge Kurulu tarafından verilen imar Malatya Belediye Meclisi'nin 02.05.2007 tarih ve 83 sayılı kararıla kabul edilmiş, Konağın bulunduğu adanın tamamında (1 No.lu parsel hariç) yapılașma tamamlanmıștır. Sadece 1 No.lu parselde yapılaşma durdurulmuş olup bu da bir çelişki yaratmaktadır. Diğer parsellerdeki yapılaşma da en az 1 No.lu parselde önerilen yapılaşma kadar konağın kütle ve gabaris ve algılanabilirliğini/görünebilirliği bakımından sıkıntı yaratmaktadır. Diğer parsellerde olmayan bir durum olarak da 1 parsel ile Konak (7 parsel) arasında 7 metrelik imar yolu ayrılmıs, parselin Konak tarafından 5 ile 13,31 metre yaklaşma mesafesi belirlenmiştir. 1 No.lu parsel ile konağın etrafındaki diğer parseller arasındaki yaklaşma mesafeleri yapıların gabarisi de dikkate alındığında belli bir standart oluşturmamaktadır. Dolayısıyla aynı ya da farklı kurumların benzer durumlarda çok farklı kararalar verdikleri görülmektedir. Bu durum da gerek yönetsel gerekse hukuki açıdan belli bir standardın oluşmasına engel olmaktadır

Nazım imar planında Karakaş Konağı'nın batısında yer alan 1324 ada 1 parselin ve doğusunda ki 1324 ada 2, 3, 4, 5, 6 sayılı parseller "Konut + Ticaret $(K+T)$ " kullanımına ayrılmış; 1324 ada 1 parsel ile aynı adanın 2, 3, 4, 5 sayılı parsellerinin "Blok nizam 5 katlı Konut + Ticaret $(K+T)$ " kullanımına ayrılmış ve yapılaşma hakları da TAKS:0,40-KAKS:2,00 olarak belirlenmiştir. Koruma Bölge Kurulu kararı ve Malatya Belediye Meclisi kararı ile 2007 yılında onaylanan imar planında 1324 ada 1, 2, 3, 4, 5 6 No.lu parsellerde inşa edilecek yapılara ilişkin yapı yaklaşma mesafeleri şematik gösterildiği gibi çoğu yerde de ölçüleri gösterilmiştir. 1324 ada 2 parselde 5 metre çekme mesafesi bırakılarak 5 katlı binanın, aynı ada- 
nın 3, 4, 5 sayılı parsellerinde 3 metre çekme mesafesi bırakılarak bitişik nizam 4 katlı ve aynı adanın 6 parselinde de bitişik nizam 2 katı bina inşa edilmiş olup, konağın doğu tarafında yapılaşma tamamlanmıştır. Bu yapılaşma kültür varlığı konumundaki Karakaş Konağı'nın doğu, güneydoğu ve kuzeydoğu ekseninde görünebilirliğini/algılanabilirliğini olumsuz yönde etkilemiştir. İnşa edilen bu yapıların konak ile aralarındaki çekme mesafelerinin çok yetersiz oluşu ve bu yapılara verilen 4 ya da 5 kat bina yüksekliği, yapının kütle ve gabarisi ile uyumsuz bir yapılaşmanın ortaya çıkmasına neden olmuştur. Hatta bu yapılar Karakaş Konağı'nın çok yakın mesafelerden bile görünebilirliğini/algılanabilirliğini ortadan kaldırmıştır. Bu olumsuz durum yapının sadece batı, kuzeybatı ve güney batı ekseninde bir görünürlük kazanmasına imkan hazırlarken yeni inşa edilen yapı ile (1 No.lu parsel) bu cephelerden sağlanan görünürlük de tamamen ortadan kalkmıştır (Görsel 12-13).
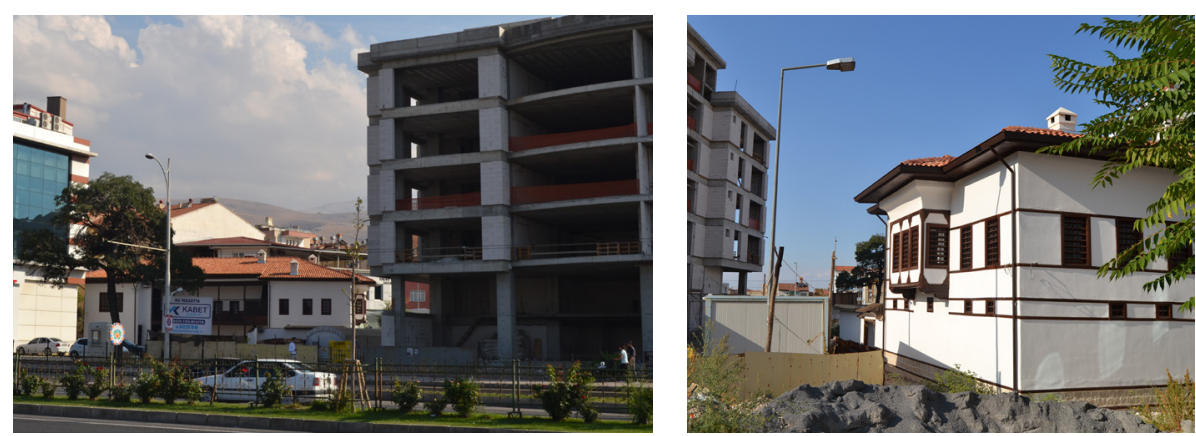

Görsel I2. Cepheden Görünümü (Solda)

Görsel I3. Güney Batı Cepheden Görünümü (Sağda)

Malatya Belediyesi İmar ve Şehircilik Müdürlüğü'nün 11.05.2009 tarihli imar planına göre düzenlenen "İmar Çapı"nda 1 No.lu parsel için, blok nizamda ve bina yüksekliğinin 15,50 metre olacağı öngörülmüş olup, bu yükseklik konağın diğer tarafını kapatan yapılarla aynı ölçüdedir. İmar iznine göre; inşa edilecek olan yapının Karakaş Konağı'na cephe veren bölümünün kuzeyinde ve orta bölümünde 5,00 metre ve güneyinde 13,31 metre çekme mesafesi uygulanması ile arka bahçeyi olușturan 17,00 metrelik yol tarafında 5,00 ve 9,93 metre çekme mesafesi bırakılması, parsel üzerinde inşa edilen yapının, konak üzerindeki imaj baskııını, konağın görünebilirliği/algılanabilirliği üzerindeki olumsuz etkisini hiçbir şekilde değiştirmemektedir. İmar izni verilmiş olan diğer parsellerin konak üzerindeki olumsuz etkisi ortada iken konağın batı tarafını tamamen kapatacak parsel üzerine de imar izni verilmesi ve belirlenen ölçülerde bir bina inşa edilmesi yapının yok edilmesi ile aynı anlamı taşımaktadı. Ancak burada şunu da belirtmek gerekir ki 1324 adanın 2, 3, 4, 5, 6 No.lu parsellerde konak ile arasında 5,00 ve 3,00 metre çekme mesafesi bırakılarak binalar inşa edilmiştir. Bu inşa edilen yapılara göre aynı ada 1 No.lu parselin çekme mesafesinin daha fazla olduğunu da belirtmekte fayda vardır. Yani diğer parsellere verilen yapı iznin yanında daha fazla çekme mesafesi bırakılan bir parsele inşa izninin verilmemesi de çelişki yaratmaktadır (Görsel 13).

Ülkemizde 2863 sayılı Kültür ve Tabiat Varlıklarını Koruma Kanunu'nun [KTVKK] "Korunma alanı ile ilgili karar alma yetkisi" ara başlıklı 8 inci maddesine göre şu hüküm düzenlenmiştir:

Yedinci maddeye göre tescil edilen korunması gerekli kültür ve tabiat varlıklarının korunma alanlarının tesbiti ve bu alanlar içinde inşaat ve tesisat yapılıp yapılamayacağı konusunda karar alma yetkisi Koruma Kurullarına aittir....Korunma alanlarının tespitinde, korunması gerekli kültür ve tabiat varlıklarının korunması, görünümlerinin ve çevreleri ile uyumlarının muhafazası için yeteri kadar korunma alanına sahip olmaları dikkate alınır (KTVKK, 1983: madde 8).

“Korunma alanı: Taşınmaz kültür varlıklarının muhafazaları veya tarihi çevre içinde korunmalarında etkinlik taşıyan korunması zorunlu olan alanları,..." (Korunması Gerekli Taşınmaz Kültür Varlıklarının ve Sitlerin Tespit ve Tescili Hakkında Yönetmelik, 2012: madde 3) ifade eder.

Ayrıca Kültür ve Tabiat Varlıklarını Koruma Yüksek Kurulu'nun [KTVKYK] 5.11.1999 tarih ve 664 No.lu Illke Kararına göre, Sit Alanları Dışındaki Üzerinde Korunması Gerekli Taşınmaz Kültür Varlığı Bulunan Parsellerin, Koruma Alanı üzerinde olduğu belirtilmiştir. Bu kararda "Koruma alanı belirlenmemiş sit alanı dışındaki tescilli parsellerde, bu parsele komşu olan veya aralarından yol geçse dahi bu parsele cephe veren parsellerin koruma alanı olarak kabul edilmesine, bu alanlarda gelecekte yapılacak uygulamalarda aksaklıklara neden olunmaması için Koruma Kurulu'ndan karar alınmadan herhangi bir uygulama yapılamayacağına" hükmü düzenlenmiştir (KTVKYK, 1999).

Yukarıda adı geçen yasal düzenlemeler göstermektedir ki, ülkemizde "Koruma Alanı" tanımlaması yapılırken genel çerçeve hakkında bir sınırlamaya gidilmiş olup, asıl belirleyici ve karar verici makam olarak "Koruma Kurulları" gösterilmiştir. "Korunması gerekli kültür ve tabiat varlıklarının korunması, görünümlerinin ve çevreleri ile uyumlarının muhafazası için yeteri kadar korunma alanına sahip olmaları dikkate alınır" gibi çok net ve belirleyici olmayan tanımlamalar birçok sorunun yaşanmasına neden olmaktadır (Net tanımlamaların yapılması ise her eserin kendi özel durumu 
söz konusu olduğundan dolayı da imkansızlaşmaktadır). Kurullar arasında ortak bir anlayış kabul görmez iken, bölge kurullarının almış olduğu bazı kararlar bir üst kurul olan Kültür Varlıklarını Koruma Yüksek Kurulu tarafından da reddedilebilmektedir. Yalnız ulusal alanda değil uluslararası alanda da "Koruma Alanı", yani kültür varlı̆̆ını oluşturan, görünebilirliğini/algılanabilirliğini belirleyen ve imaj görünümüne etki eden çevresel unsurlar çok önemsenmiştir. Ancak yapılan uluslararası antlaşmalarda da bu alanların belirlenmesi ile ilgili net kriterler oluşturulmamış/oluşturulamamış ve insiyatif üye ülkelere bırakılmıştır. Gerek Birleşmiş Milletler Eğitim, Bilim ve Kültür Örgütü [UNESCO] gerekse Uluslararası Anıtlar ve Sitler Konseyi [ICOMOS] tarafından konu ile ilgili birçok antlaşmalar yapılmış olup, ülkemiz de bu anlaşmalara imza atarak alınan kararları kabul etmiştir. Uluslararası geçerliliği ve bağlayıcılığı olan bu anlaşmalarda en çok dikkat çeken hususlardan bir tanesi kültür varlıklarının muhafaza edilmesi kadar, bu eserlerin, çevrelerinin, görünülebilirliklerinin/algılanabilirliklerinin de aynı derecede önemsenmesidir. Nasıl taşınmaz bir kültür varlığının yerinden sökülerek başka bir yere götürülmesi ile yok edilmesi aynı değerlendirilmiş ise; bir eserin görünümünün/algılanabilirliğinin engellenmesi ile o eserin yok edilmesi de aynı görülmüştür.

UNESCO tarafından 1954 yılında kabul edilen Lahey Sözleşmesi'nde (Silahlı Çatışma Halinde Kültürel Varlığın Korunması Sözleşmesi) (1954: madde 4), bir kültür varlığının çevresindeki eserlerden olumsuz anlamda etkilenmesi bağlamında şu tespitler ortaya konmuştur: "Yüksek Akit taraflar.....ülkelerinde bulunan kültürel varlıklarla bunların korunma tesislerini ve civarlarındaki yerleri ve eserleri... tahrip veya bozulmaya maruz bırakabilecek maksatlar için kullanmaktan sakınmak ve bu mallara karşı her türlü düşmanca davranıştan kaçınmak suretiyle işbu mallara riayeti taahhüt eder."

UNESCO tarafından 1968 yılında kabul edilen Kamusal veya Özel Yapım Çalışmalarınca, Tehdit Edilen Kültürel Varlıkların Korunmasına İlişkin Tavsiye Kararı [KÖYÇTEKVKITK], "Alınan önleyici ve düzeltici önlemler, kültürel varlıkların söz konusu varlıklara hasar vermesi veya bu varlıkları yok etmesi muhtemel kamusal ya da özel yapım çalışmalarından korunması amacını taşımalıdır" (KÖYÇTEKVKITK, 1968: madde 8) görüşünü ortaya koymuştur. Aynı tavsiye kararında kültür varlığı konumundaki anıtların, tarihi kentlerin imar planlamasında belirleyici bir role sahip olması da ortaya konulmuştur:

Kentsel ya da kırsal merkezlerdeki tarihi bölgeler ve geleneksel yapı gruplarının (kültür varlıklarının)... ortam ve karakterini korumak için, tarihsel ve sanatsal değer taşıyan yapıların yenilenebileceği ve yeni yapıların tip ve tasarımının yerleştirilebileceği ölçüde denetim uygulanması gibi düzenlemeler benimsenmelidir. Anıtların korunması, özellikle de tarihi kent ve semtlerde şehirlerin imarı için gerçekleştirilen iyi tasarlanmış tüm planların kesin şartı olmalıdır. Benzer düzenlemeler, söz konusu varlığın bağlantılarını ve karakterini korumak için, listelenmiş bir anıtı veya ören yerini çevreleyen alanı da kapsamalıdır (KÖYÇTEKVKITK, 1968: madde 24-b).

1992 tarihinde ICOMOS tarafından kabul edilen Yeni Zelanda Tüzüğü (Kültürel Miras Değeri Taşıyan Yerlerin Korunması ile Illgili Tüzük) [IYZ] (1992: madde 6), "Bir yerin tarihi ortamı da o yer ile birlikte muhafaza edilmelidir" derken çevrenin kültür varlığının muhafazasındaki önemine dikkat çekmektedir. Aynı tüzük, tarihi bir yapının bulunduğu alanın genellikle o yapının kültürel miras değerinin ayrılmaz bir parçası (IYZ, 1992: madde 6) olduğunu ortaya koymakta ve bu çevresel unsurların ve yapıların durumunu da bağlayıcı bir hale getirmektedir.

Tarihi yapıların korunması ile ilgili olarak 1999 tarihli ICOMOS Burra Tüzüğü (Kültürel Öneme Sahip Yerlerin Korunması Amaçlı Avustralya) (1999: madde 8), "Tarihi bir alanın korunması, görsel düzenlemeleri ve tarihi dokuya katkıda bulunan diğer parçalarının da korunmasını beraberinde getirir. Nitekim yeni yapılanma, yıkım, izinsiz müdahaleler veya ortamı olumsuz yönde etkileyecek diğer değişiklikler uygun değildir" açıklamasıyla tarihsel ve kültürel değerin devamlılığının sağlanması için kültür varlığı konumundaki yapıların çevrelerindeki deki unsurların göz ardı edilemeyeceğine dikkat çekmektedir.

ICOMOS'un 2005 yılında kabul etmiş olduğu Miras Yapılarının, Ören Yerlerinin ve Alanlarının Muhafaza Edilmesi ile ilgili Xi'an Deklarasyonu'nda [MYÖYAMEIXD] "Miras yapıları, ören yerleri ve alanları ile ilgili mevzuat, düzenlemeler ve koruma, muhafaza etme ve idare etme ilkeleri, bu yerlerin etrafında, mekânın önemini ve ayırt edici özelliklerini yansıtan ve muhafaza eden bir koruma bölgesinin ya da tampon bölgenin kurulmasına katkıda bulunmalıdır" (MYÖYAMEIXD, 2005: Madde 6) tavsiyesinde bulunulmustur. Aynı deklarasyon ayrıca "Miras yapıları, ören yerlerinin ve alanların bulunduğu mekanlar dahilindeki gelişmeler, bu yerlerin değerini ve ayırt edici özelliğini olumlu bir biçimde yorumlamalı ve bunlara katkıda bulunmalıdır" (MYÖYAMEIXD, 2005: madde 8) görüşünü ifade ederken benzer bir çok yaklaşımla aynı düşünceye sahip olduğunu da ortaya koymuştur.

ICOMOS tarafından kabul edilen 1931 tarihli Restorasyon Tüzüğü'nde (1931: madde 6), "Anıta ve geçirdiği dönemlere olduğu kadar çevresine de saygııı olunmalıdır. Anıtın çevresindeki yapıların yıkılarak uygunsuz bir 
biçimde yalnız bırakılmasına veya çevresinin niteliği, kütlesi, üslubu ile rahatsız edici yapılarla sarılmasına engel olunmalıdır" ifadesi mekan, çevre ve koruma bağlamında yüzyılın başında bile bir hassasiyetin var olduğunu ortaya koymaktadır.

Kent, kültür varlığı ve koruma bakımından birçok eksikliği oradan kaldıran ve ICOMOS tarafından 1964 tarihinde kabul edilen VenedikTüzüğü (1964: madde 6), "Anıtın korunması, ölçeği dışına taşmamak şartıyla çevresinin de bakımını içine almalıdır.... Kütle ve renk ilişkilerini değiştirecek hiçbir yeni eklentiye, yok etmeye, ya da değiştirmeye izin verilmemelidir" diyerek çevre ve bakım bakımından eserin çevreden ve çevrenin de eserden ayrı düşünülemeyeceğini ortaya koymaktadır.
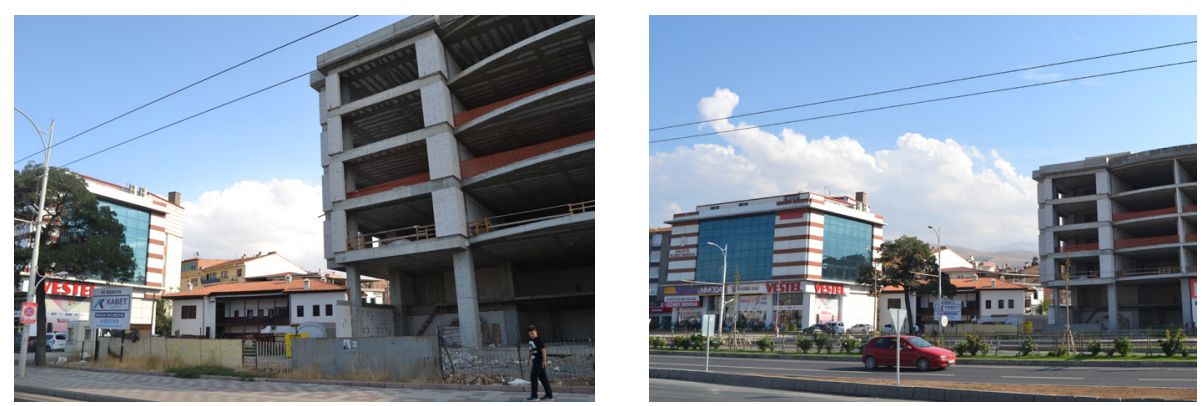

Görsel 14 Cepheden Görünümü (Solda)

Görsel 15. Cepheden Görünümü (Sağda)

Mimari konumdaki bir kültür varlığının görünürlüğü/algılanabilirliği sadece 10 ya da 15 metrelik bir alandan sağlanamaz. İnşa edilen yapılar, her ne kadar Karakaş Konağı ile arasında yer yer farklı ölçülerde çekme mesafelerine sahip olsalar da, yapılara verilen yükseklikle, konağın algılanabilir cephesi tamamen ortadan kaldırılmıştır (Şekil 14-15). Kaldı ki kültürel açıdan değere sahip bir mimari yapının etrafındaki koruma alanının tespiti, sadece yapının görünebilirliğiyle ilgili olmayıp, yapı silüetinin olumsuz yönden etkilenmemesi ile de direk bağlantılıdır. Kent silüetlerinin şekillendirilmesinde kültür varlığı konumundaki mimari yapılar belirleyici olmaktadır/olmalıdır. Öyle ki kültürel ve tarihsel değere sahip, farklı geleneklere ve düşünsel başarılara şahit bu yapılar, dünyanın birçok kentinde -özellikle gelişmiş batılı ülke kentlerinde- ortaya çıkan panoramik görüntünün ana taşıyıcı unsuru olma özelliğine sahiptir. Ama maalesef ülkemiz bu hususta gelişmiş batılı ülkelerin göstermiş olduğu hassasiyete henüz tam anlamıyla ulaşamamıştır. Nitekim Dolmabahçe Sarayı'nın (İstanbul) arkasında bulunan ve hukuki açıdan kaçak/yasak olduğu sabit görülen "Gökkafes" (yapı ile Saray arasındaki çekme mesafesi oldukça fazladır) adlı bina bu hususta güzel bir örnek olarak değerlendirilmektedir. Mevcut yapının yargı tarafından kaçak olarak değerlendirilmesinin, Saray ile arasındaki çekme mesafesiyle herhangi bir ilgisi olmayıp, asıl sorun kaçak yapının Saray silüeti üzerindeki imaj baskısı ile ilintilidir. Aynı durum tarihi İstanbul silüetini bozan gökdelenlerle de ilgilidir. Nitekim Tarihi yarımadanın arka tarafına (Zeytinburnu) inşa edilen ve Sultanahmet Cami, Ayasofya, Topkapı Sarayı ve diğer kültür varlığı konumundaki yapıları gölgede bırakan gökdelenlerin de bu yapılara uzaklığı çok fazla olup, asıl sorun bu gökdelenlerin mevcut yapılar üzerindeki imaj görünümüyle ilintilidir.

\section{Sonuç}

Uluslararası alanda yapılan ve dünya devletlerinin büyük çoğunluğu (ülkemiz dahil) tarafından da imzalanan anlaşmalar; kültür varlığının çevresinin de eserlerle aynı değere sahip olduğunu ortaya koyarken, bu eserlerin etrafında yapılacak olan yapılaşmalarla ilgili olarak herhangi bir kriter belirlememiş, asıl belirleyici kriterleri üye ülkelere bırakmıştır. Bu da birçok ülke açısından göreceli bir durumun oluşmasına imkân hazırlamıştır. Hatta aynı ülke içerisinde bile farklı uygulamaların yaşanmasına neden olmuştur. Nitekim ülkemiz açısından da Bölge Koruma Kurullarının almış oldukları kararlarda da bir birliktelik görülmediği ortadadır. Ancak gelişmiş ülkelerdekiörneklerincelendiğinde, kültürel değere sahip eserlerin etrafında herhangi bir yapılaşmaya izin verilmediği ve eserlerin dört tarafından, çok uzak mesafelerden de, algılanmasına imkân sağlandığı görülmektedir. İmar planlarında bu eserlerin çevresine inşa edilecek binaların çekme mesafeleri, kat yükseklikleri vb. birçok etken mevcut kültür varlığının pozisyonuna göre değerlendirilmiş ve bu eserlerin görünümlerinin engellenmesine yönelik hiçbir girişim kabul görmemiştir.

Mevcut imar durumu ile özgün ve tescilli bir yapı olan Karakaş Konağı'nın kütle ve gabarisi arasında uyumsuz bir yapılaşma ortaya çıkmış, yapının görünebilirlik/algılanabilirlik düzeyi ile birlikte yapı silüetinin olumsuz yönde etkilendiği görülmüş, bu yapılaşmanın imar mevzuatı ve kamu yararına fayda sağlamadığı gibi bununla beraber bir çevre kirliliği de yarattığı görülmektedir. Kültürel birikime sahip olan konak, kendi yüksekliğinin üstünde yapıların ortasında kalmış ve çevreden görünebilirliğini tamamen yitirmiştir. Bu durum gelecekte konağın başka amaçlar doğrultusunda kullanılmahedefine de ciddianlamdazararvermiş, konağıalıp da ticariamaçlı kullanacak işletmeleri de olumsuz yönde etkilemiştir. Ancak burada şuna da dikkat edilmelidir ki, tescillenmiş olup özel mülke ait olan taşınmaz kültür varlıklarının sahiplerinin de kesinlikle mağdur edilmemesi gerekmektedir. 
Kıymetli bir taşınmaz kültür varlığına sahip olan bir şahıs (çoğunlukla bu yapılar şehrin en çok rant getiren bölgelerinde bulunmaktadır) elindeki bu değerin menfaatlerinden de bir şekilde yararlanmalıdır. En azından o eserin kendisinden ya da bulunduğu arsasından yararlanamıyorsa da, bu taşınmazların değerlerinin karşılığının şahsa ödenmesi gerekmektedir. Öyle ki bir şahsın elinde bulunan ve çok fazla değere sahip olan taşınmaz kültür varlığını tescilleyip kişinin o eserden ve bulunduğu alandan yararlanmasını engellemek, kişisel hakların korunması bakımından da sıkıntı yaratmaktadır.

\section{Kaynakça}

Ahunbay, Z. (20I4). Tarihi Çevre Koruma ve Restorasyon. İstanbul: YEM Yayın.

Bektaş, C. (200I). Koruma Onarım. İstanbul: Literatür Yayıncılık.

Burra Tüzüğü: Kültürel Öneme Sahip Yerlerin Korunması Amaçlı Avustralya-ICOMOS Tüzüğ̈̈. (1999). Erişim Adresi: http://australia.icomos.org/wp-content/uploads/The-BurraCharter-2013-Adopted-31.10.20I3.pdf

Erder, C. (1975) Tarihi Çevre Bilinci, Ankara.

Harvey, J. (1972). Conservation of Buildings, Londra.

Kamusal veya Özel Yapım Calıșmalarınca, Tehdit Edilen Kültürel Varlıkların Korunmasına İlişkin Tavsiye Kararı. (1968). Erişim Adresi: http://portal.unesco.org/en/ev.php-URL_ $I D=13085 \&$ URL_DO =DO_TOPIC\&URL_SECTION $=201 . \mathrm{html}$

Korunması Gerekli Taşınmaz Kültür Varlıklarının ve Sitlerin Tespit ve Tescili Hakkında Yönetmelik. (20/2). T.C. Resmî Gazete, 28232, 13 Mart 2012.

Kültür ve Tabiat Varlıklarını Koruma Yüksek Kurulu. (1999). 664 No.lu Illke Kararı, 05.II.1999.

Kültür ve Tabiat Varlıklarını Koruma Kanunu. (1983). T.C. Resmi Gazete, I8II3, 2 I Temmuz 1983.

Lahey Sözleşmesi: Silahlı Çatışma Halinde Kültürel Varlığın Korunması Sözleşmesi. (1954). T.C. Resmi Gazete, I2 I45, Kasım 1965.

Malatya Kültür Envanteri (20/4). Malatya II Kültür ve Turizm Müdürlüğü, Malatya.

Miras Yapılarının, Ören Yerlerinin ve Alanlarının Muhafaza Edilmesi ile Ilgili Xi'an Deklarasyonu. (2005). Erişim Adresi: https://www.icomos.org/xian2005/xian-declaration. htm

Restorasyon Tüzüğ̈̈. (193I). Erişim Adresi: http://www.restoraturk.com/index.php/ilgilikanun-ve-mevzuat/345-carta-del-restauro-icomos-1931

Tont, S.A. (1999). Sulak Bir Gezegenden Öyküler. Ankara: TÜBITAK Popüler Bilim Kitapları.

Yeni Zelanda: Kültürel Miras Değeri Taşıyan Yerlerin Korunması ile Illgili Tüzük (1992). Erișim Adresi: http://docplayer.biz.tr/37522326-/comos-yeni-zelanda-kulturel-mirasdegeri-tasiyan-yerlerin-korunmasi-ile-ilgili-tuzuk-icomos-1992.html 


\section{Internet Kaynakları}

Internet: Kara Bahtlı Konak (20/7) Web: http://tayproject.org/haberarsiv20 I 42.html adresinden 06.07.20I7'de alınmıştır.

Internet: Karakaş Konağı Yandı (2017). http://www.malatyasonsoz.com.tr/

haber-34590__Karakas_Konagi_yandi.html adresinden 06.07.2017'de alınmıştır.

Internet: Karakaş Konağı Aslına Uygun Restore Ediliyor

http://www.malatya.bel.tr/icerik//8/2969/karakas-konagi-aslina-uygun-restore-ediliyor. aspx adresinden 06.07.2017'de alınmıştır.

Internet: Venedik Tüzüğü. (1964). Erişim Adresi:

http://www.icomos.org.tr/Dosyalar/ICOMOSTR_06 I 288600 / 496825607.pdf adresinden 06.07.20I7'de alınmıştır.

\section{Görsel Kaynakları}

Görsel I: http://malatyahaber.com/haber/karakas-konaginda-onarim-basladi/ adresinden

18 Ekim 2017 tarihinde alınmıştır.

Görsel 2: Yazar tarafindan çekilen fotoğraf, 2017

Görsel 3: Yazar tarafindan çekilen fotoğraf, 2017

Görsel 4: Yazar tarafindan çekilen fotoğraf, 2017

Görsel 5: Yazar tarafindan çekilen fotoğraf, 2017

Görsel 6: Yazar tarafindan çekilen fotoğraf, 2017

Görsel 7: http://wowturkey.com/forum/viewtopic.php?t=924I6\&start $=25$ adresinden 20 Ekim 2017 tarihinde alınmıştır.

Görsel 8: http://siu2015.inonu.edu.tr/ adresinden 15 Aralık 2017 tarihinde alınmıştır.

Görsel 9: Yazar tarafindan çekilen fotoğraf, 2017

Görsel I0: Yazar tarafindan çekilen fotoğraf, 2017

Görsel II: Yazar tarafindan çekilen fotoğraf, 2017

Görsel I2: Yazar tarafindan çekilen fotoğraf, 2017

Görsel 13: Yazar tarafindan çekilen fotoğraf, 2017
Görsel 14: Yazar tarafindan çekilen fotoğraf, 2017

Görsel 15: Yazar tarafindan çekilen fotoğraf, 2017 